\title{
ANALISIS RESPON TANTANGAN YANG DIHADAPI \\ PENGAJAR TERHADAP E-LEARNING DI \\ POLITEKNIK PELAYARAN SORONG
}

\author{
Lilik Yulianingsih $^{1}$; Arizal Hendriawan ${ }^{2}$; \\ Ariandy Syamsul Bhahri ${ }^{3}$; Muhammad Risyal ${ }^{4}$ \\ ${ }^{1}$ Politeknik Pelayaran Sorong
}

\begin{abstract}
This Research Focused On The Findings Of The Questions On The Problem Research, Namely "What Are The Challenges Faced By The Teacher Toward E-Learning?". This Research Used The Social Constructivism Pattern Model (The Social Constructivism Paradigm) As A Qualitative Research Framework To Interpret The Issues Related To This Research (Crotty, 1998). Then, The Researcher Used The Question-List Model (Questionnaire) As A Tool For Data Collection, As Suggested By Sugiyono (2010). Therefore, Data Analysis That Used In This Study Is By Reducing Data (Data Reduction), Displaying Data (Data Display), And Concluding, As Suggested By Miles \& Huberman (1994). Therefore, Researchers Provided Several Solutions To Overcome The Difficulties Faced By Teachers As Challenges To E-Learning In The Discussion And Conclusions Of This Research.
\end{abstract}

\begin{abstract}
Abstrak
Penelitian ini difokuskan terhadap temuan-temuan dari pertanyaan pada rumusan masalah, yaitu: "Tantangan apa sajakah yang dihadapi pengajar terhadap e-learning?". Penelitian ini telah meggunakan model pola konstruktivisme sosial (the social constructivism paradigm) sebagai kerangka penelitian kualitatif untuk menginterpretasikan isu-isu yang berhubungan dengan penelitian ini (Crotty, 1998). Kemudian, peneliti telah menggunakan model daftar-daftar (angket) pertanyaan sebagai alat untuk pengumpulan data, sebagaimana yang telah disarankan oleh Sugiyono (2010). Oleh karena itu, analisa data yang akan digunakan dalam penelitian ini yaitu dengan cara pengurangan data (data reduction), tampilan data (data dispay), dan penyimpulan (concluding), sebagaimana yang telah disarankan oleh Miles \& Huberman (1994). Maka dari itu, peneliti telah memberikan beberapa solusi untuk mengatasi kesulitan-kesulitan yang dihadapi pengajar sebagai tantangan terhadap e-learning di dalam pembahasan dan kesimpulan pada penelitian ini.
\end{abstract}

Kata kunci: Tantangan Pengajar, E-Learning. 


\section{PENDAHULUAN}

\subsection{Latar Belakang}

Di era 4.0 ini, proses belajar mengajar (PBM) di Indonesia selama ini masih menggunakan pertemuan kelas secara regular atau tatap muka di dalam kelas. Cara tersebut masih dianggap sangat efektif untuk meningkatkan kualiatas pendidikan bangsa kita. Sehingga, sejakawaltahun 2020 tepatnya dipertangahan maret telah diberlakukannya proses belajar mengajar jarak jauh dengan menggunakan jaringan internet atau yang kita sebut dengan e-learning .

Pemerintah Indonesia menganggap $E$ learning sangat efektif untuk mengatasi permasalahan pendidikan yang dialami saat ini akibat COVID-19 sementara ini. Sebenarnya, pembelajaran jarak jauh ini sudah dilakukan oleh banyak instansi pendidikan di dunia atau bahkan beberapa instansi di Indonesia sendiri. Namun, tetap saja hal ini masih termasuk sangat baru bagi para peserta didik bahkan para pengajar di Indonesia.

Para peserta didik diharuskan untuk bisa mengakses jaringan internet agar dapat mengukuti proses belajar mengajar jarak jauh. Selain itu, para guru juga harus selangkah lebih maju di dalam e-learning tersebut. Hal ini merupakan tantangan tersendiri untuk para pengajar dalam mengimplementasikan ilmu kepada peserta didik. Mereka ditantang untuk meningkatkan kemampuan dalam mengikuti perkembangan teknologi.

Namun, Beberapa daerah terpencil belum mampu untuk mengakses jaringan internet. Selain itu, peralatan elektronik seperti laptop maupun gadget masih cukup mahal bagi mereka yang tinggal di pedalaman. Dan juga, mengenai penggunaan kuota internet yang harganya dianggap cukup mahal bagi beberapa peserta didik yang berada pada ekonomi menengah kebawah.

Politeknik Pelayaran Sorong adalah salah satu institusi yang sedang melakukan pembelajaran jarak jauh atau e-learning di tengah-tengah pandemic ini. Maka dari itu, peneliti tertarik untuk meneliti berbagai tantangan atau kesulitan yang dihadapi oleh para pengajar selama e-learning berangsung di Politeknik Pelayaran Sorong.

\section{TINJAUAN PUSTAKA}

\subsection{E-Learning}

E-learning adalah pembelajaran dengan menggunakan elektronik atau sistem pendidikan menggunakan computer yang membuat kita dapat belajar di mana saja dan kapan saja. Hal tersebut telah berkaitan dengan pernyataan Sri Rahayu Candrawati (2010) bahwa proses belajar mengajar menjadi sangat fleksibel karena siswa/ mahasiswa bisa belajar sesuai dengan waktu yang mereka miliki. Itu berarti bukan hanya para pelajar yang mempunyai fleksibel waktu tetapi berlaku juga untuk para pengajar di mana mereka bisa mengajar sesuai waktu yang dimiliki, meski harus tetap dikontrol oleh pihak institusi itu sendiri.

Menurut Ahmad Cucus dan Yuthsi Aprilinda (2016), bahwa dalam proses belajar mengajar, konten pembelajaran adalah hal yang paling penting. Dalam pembelajaran 
jarak jauh (e-learning), konten harus diperhatikan lebih utama karena dalam elearning peserta belajar memperoleh materi dengan proporsi lebih besar dari membaca isi materi secara mandiri ketimbang bertatap muka langsung dengan pengajar. Oleh karena itu, pengajar harus lebih berinovasi dalam pembuatan konten yang menarik peserta didik untuk lebih termotivasi dalam mengikuti e-learning. Konten yang menarik itu bisa berupa tampilan power point atau isi materi yang lebih mudah diterima oleh para pelajar.

\subsection{Tantangan dalam Mengajar}

Menurut Aslan (2017), bahwa pengajar bukan hanya untuk ditiru, tetap mereka harus mampu memotivasi peserta didiknya agar semangat dalam belajar. Hal tersebut harus dicontohi oleh pengajar sendiri dengan menunjukkan semangat dalam mengajar, sehingga dalam hati guru tertatanam konsep bahwa mengajar harus dari hati bukan hanya sekedar memberikan materi agar terciptanya anak didik yang beriman, berilmu, bertakwa dan berkarakter yang siap menghadapi tantangan pendidikan di era 4.0 ini.

Menurut Riska, Paulus dan Ridi (2016), bahwa dengan perkembangan pendidikan saat ini, di mana situs atau media pembelajaran telah digunakan oleh para pengajar dalam melakukan proses belajar mengajar (PBM) dalam menggunakan media pembelajaran e-learning, tantangan yang dihadapi para guru menjadi factor yang menentukan apakah e-learning akan terus diterapkan sebagai metode pembelajaran di suatu lembaga pendidikan. Faktor keberhasilan dalam pembelajaran menggunakan media e-learning akan menjawab bagaimanacara mengatasi tantangan dari penggunaan e-learning .

\section{METODE PENELITIAN}

\subsection{Tempat dan Waktu Penelitian}

Penelitian telah dilaksanakan di area Politeknik Pelayaran Sorong pada bulan Agustus s/d Oktober 2020.

\subsection{Alat dan Bahan}

Ada pun alat dan bahan yang telahdigunakanuntukpenelitiansebagai berikut:

1. Kertas HVS

2. Pena

3. Voice recorder

4. Daftar pertanyaan (angket):

1) Bagaimanakah persepsi pengajar pada e-learning?

2) Bagaimanakah respon para pelajar terhadap e-learning?

3) Bagaimanakah cara pengajar berinovasi dalam membuat konten untuk materi pada e-learning?

4) Apakah keuntungan dari e-learning bagi pengajar?

5) Apakah kekurangan dari $e$ learning?

6) Apakah e-learning wajib diaplikasikan untuk kedepannya?

\subsection{Jenis Penelitian}

Penelitian ini telah menggunakan model pola konstruktivisme sosial sebagai kerangka dalam penelitian kualitatif untuk menginterpretasikan isu-isu yang berkaitan 
dengan penelitian ini. Hal tersebut telah dijelaskan oleh Crotty (1998), bahwa:

1) Para peneliti kualitatif harus menggunakan pertanyaan-pertanyaan terbuka (open-ended questions)

2) Para peneliti harus memahami latar belakang dari para responden.

3) Peneliti harus menciptakan signifikasi di dalam induktif dari data asli yang telah dikumpulkan.

\subsection{Data Penelitian}

Data penelitian telah dikumpulkan dengan menggunakan model angket (daftardaftar pertanyaan). Model angket adalah teknik pengumpulan data dengan memberikan beberapa pertanyaan tertulis kepada responden (Sugiyono, 2010). Oleh karena itu, peneliti telah membuat beberapa pertanyaan tertulis yang dijawab sesuai dengan pendapat para responden. Dalammenampilkanhasildari data penelitian oleh responden, peneliti hanya menggunakan inisial untuk menjaga kerahasiaan identitas responden.

\subsection{Pelaksanaan Penelitian}

Pelaksanaan penelitian ini telah dilakukan secara berkala sesuai waktu dan tempat penelitian yang dijadikan fokus penelitian. Maka, pelaksanaan penelitian ini dilakukan secara berkala dengan tidak mengganggu jam mengajar para responden di area Politeknik Pelayaran Sorong.

\subsection{Metode Analisis Data}

Pada penelitian ini, peneliti telah menggunakan analisis wacana (discourse analysis) di dalam temuan-temuan, daftar temuan, dan menganalisa data tersebut sebagaimana yang telah disarankan oleh Miles \& Huberman (1994), yaitu pengurangan data (data reduction), tampilan data (data display), dan penyimpulan (concluding). Hal itu sangat bermanfaat ketika menganalisa data karena peneliti menyaring data per data melalui pengurangan data dan menampilkan data melalui tampilan data. Pada akhirnya, peneliti telah mendeskripsikan kesimpulan dari data yang telah ditemukan.

\section{HASIL}

\subsection{Temuan-Temuan}

Sebagai penelitian kualitatif, peneliti telah membuat dan menagajukan beberapa pertanyaan di dalam angket yang telah disebarkan kepada para pengajar sebagai responden di area Politeknik Pelayaran Sorong. Pertanyaan-pertanyaan tersebut bersifat terbuka (open-ended). Kemudian, peneliti telah memahami latar belakang para responden, lalu melakukan signifikasi di dalam induktif dari data asli yang telah dikumpulkan (Crotty,1998).

Melalui data analisa yang digunakan oleh Miles \& Huberman (1994), peneliti telah menemukan beberapa temuan yang berhubungan dengan topic tantangan yang dihadapi oleh pengajar terhadap e-learning. Temuan-temuan tersebut berdasar hasil dari angket yang telah disebarkan kepada para responden. Kemudian, peneliti telah melakukan pengurangan data (data reduction) dan menampilkan data tersebut pada bab ini (data display), serta melakukan penyimpulan (Concluding) dari hasil temuan- 
temuan tersebut. Setelah melakukan reduction data, peneliti telah menemukan 5 extract yang memadai untuk diwakilkan sebagai sampel penelitian.

\section{Pembahasan}

Di dalam penelitian ini, peneliti fokus pada respon para pengajar mengenai sebuah permasalahan yang telah dirumuskan kedalam 6 pertanyaan pada angket penelitian, yaitu; Tantangan apa saja yang dihadapi pengajar terhadap e-learning? Pembahasan ini merelevansikan antara respon-respon para pengajar dengan tinjauan pustaka penelitian ini.

Pada extract 1, ATB menyatakan bahwa "e-learning merupakan pembelajaran dengan menggunnakan jasa perangkat elektronika". Pernyataan tersebut selaras dengan yang dikemukakan oleh Rahayu Candrawati (2010) bahwa e-learning adalah pembelajaran dengan menggunakan elektronik. Hal tersebut terbukti dengan situasi pandemic yang terjadi saat ini. Dimana, kegiatan belajar mengajar melalui elearning tidak akan mungkin terjadi tanpa adanya media elektronika karena sangat membutuhkan jaringan internet untuk melakukan pembelajaran jarak jauh. Sehingga, pelajar dan pengajar tidak perlu bertatap muka di dalam kelas, sebagaimana yang telah dinyatakan ATB mengenai respon pelajar terhadap e-learning bahwa "memungkinkan bagi pelajar untuk tetap belajar".

Selain itu, ATB juga mengatakan bahwa Ia melakukan variasi cara mengajar agar pelajar dapat mencapai dasar kompetensi selama e-learning berlangsung. Pernyataan ATB di sini tidak merincikan variasi cara mengajar yang harus Ia lakukan, sehigga tidak menjawab mengenai inovasi di dalam membuat konten materi. Tetapi, inovasi yang dilakukan dengan melakukan bermacam variasi mengajar atau yang disebut sebagai metode mengajar termasuk di dalam memotivasi dirinya sebagai seorang guru untuk tetap melakukan proses belajar mengajar meski harus melalui jarak jauh.

ATB mengutarakan keuntungan $e$ learning yaitu mempermudah proses pembelajaran karena tidak perlu bertatap muka secara langsung, namun di sisi lain hal tersebut merupakan kekurangan dari $e$ learning itu sendiri seperti yang telah dia ungkapkan bahwa di dalam e-learning, terdapat beberapa kekurangan seperti kurangnya interaksi antar pelajar dan pengajar, pembelajaran lebih mengarah kepelatihan, dan akan menaikan aspek akadem insertasosial. Sehingga, dengan memootivasi diri sendiri, ATB mengharapkan semangatnya dalam proses pembelajaran terhadap e-learning ini dapat tersalurkan kepada para pelajar sebagai motivasi untuk tetap mengikuti pembelajaran di masa pandemic ini. Sebagaimna yang telah dikatakan Aslan (2017) bahwasanya pengajar hanya bukan untuk ditiru tetapi harus bisa juga memotivasi peserta didiknya, dan hal tersebut bisa dimulai dari memotivasi diri sendiri.

ATB pun siap menerima tantangan yang lebih kompleks kedepannya terhadap proses pembelajaran jarak jauh sebagaimana yang 
diungkapkan Riska, dkk. (2016) bahwa tantangan yang dihadapi para pengajar merupakan factor penentu diterapkannya $e$ learning sebagai metode pembelajaran oleh suatu lembaga pendidikan. Hal tersebut dapat dilihat dari respon ATB pada akhir pertanyaan, yaitu "untuk kedepannya $e$ learning wajib diaplikasikan karena tidak bisa menutup kemungkinan terjadinya perubahan sesuai kondisi jaman", sehingga memicu para pengajar untuk menguasai proses pembelajaran melalui e-learning.

Pada Extract 2, YAH mengutarakan bahwa e-learning adalah pembelajaran dengan memanfaatkan teknologi sehingga pengajar harus mempersiapkan materi atau metode mengajar sebaik mungkin. Hal tersebut relevan dengan yang telah dijelaskan oleh Ahmad dan Yutshi (2016) bahwa dalam e-learning, pengajar harus mengutamakan konten sebagai bahan ajar. Pernyataan ini pun berkesinambungan dengan respon YAH mengenai inovasi dalam membuat konten untuk materi, di mana ia tetap memberikan materi yang sama ketika pembelajaran di dalam kelas namun menggunakan metode yang berbeda. Yaitu dengan menjelaskan kembali instruksi melalui aplikasi WA, baik secara tulisan atau pun verbal melalui rekaman suara atau pun video. Seperti yang diutarakannya "instruksi biasanya saya menjelaskan kembali lewat WAG masingmasing kelas atau merekam instruksi yang dirasa taruna/i kurang paham". Namun, respon tersebut tidak menjawab mengenai pembuatan konten materi melainkan cara mengajar dari pengajar itu sendiri.

$6 \mid$ Jurnal Patria Bahari
Mengenai respon pelajar, YAH mengungkapkan "taruna/i termasuk aktif dalam kehadiran namun kurang aktif dalam mengerjakan dan mengumpulkan tugas". Di sini dapat dilihat bahwa di dalam mengajar melalui e-learning, Ia mengalami kesulitan dalam mengontrol pelajar untuk mengerjakan tugas yang diberikan, meski secara kehadiran pelajar masih terlihat aktif untuk mengikuti pembelajaran di dalam e-learning. Maka, dapat disimpulkan bahwa respon siswa ketika kurang aktif dalam mengumpulkan tugas termasuk dalam salah satu kekurangan $e$ learning sendiri, di mana pengajar mengalami kesulitan untuk mengontrol peserta didik di dalam e-learning. Sehingga, perlu diberlakukannya punishment bagi pelajar yang lalai dalam mengerjakan tugas. Namun, YAH kurang menyadari bahwa hal tersebut merupakan kekurangan e-learning, sehingga ia beranggapan bahwa kekurangan e-learning hanya mengenai sulitnya mengukur pelajar di dalam speaking skill dikarenakan kurangnya intensitas dalam bertatap muka, sebab ia mengampuh mata kuliah bahasa inggris. Sebagaimana yang ia katakan tentang kekurangan e-learning "saya mengampu mata kuliah Bahasa inggris dimana diperlukan komunikasi aktif dalam pembelajaran", ini adalah kesulitan tersendiri bagi pengajar dengan mata pelajaran tertentu yang membutuhkan lebih tatap muka untuk mengembangkan salah satu kemampuan yang ingin dicapai pada pembelajaran tersebut.

YAH beranggapan bahwa e-learning mempunyai keuntungan dalam segi 
penghematan tenaga dan pengeluaran kertas.

Seperti yang dikatakannya "Keuntungan lebih hemat tenaga dan paperless". Hal tersebut dikarenakan pengajar tidak perlu mengeluarkan suara ekstra seperti ketika mengajar di dalam kelas. Namun, ketika siswa aktif bertanya, pengajar harus menyempatkan waktu luang untuk menjawab bermacam pertanyaan mengenai instruksi yang mungkin kurang dipahami jika hanya melalui tulisan. Karena daya tangkap pelajar pasti berbeda-beda. Sedangkan mengenai paperless atau penghematan penggunaan kertas, tanpa e-learning pun bisa saja dilakukan di dalam kelas dengan memberikan materi melalui power point. Maka, keuntungan mengenai paperless tidak hanya bisa terjadi melalui e-learning, tetapi juga bisa diterapkan pada pembelajaran di dalam kelas tergantung bagaimana pengajar berinovasi dalam memberi materi ajar.

YAH juga mengatakan bahwa $e$ learning berdampak pada kesehatan karena tidak bertatap muka langsung pada masa pandemic. Untuk itu, Ia menganggap bahwa e-learning tidak wajib diterapkan kedepannya, seperti yang diungkapnnya "Menurut saya tidak wajib, kecuali dalam kasus-kasus tertentu saat pandemic seperti ini". Yang artinya, Ia beranggapan kesulitan lebih banyak ditemui dibandingkan keuntungan di dalam pembelajaran melalui e-learning. Sehingga, menurutnya e-learinng boleh dilakukan apabila terjadi situasi tertentu seperti kondisi pandemic saat ini.
Dari pernyataan tersebut, dapat disimpulkan bahwa YAH menganggap pelajar belum siap untuk mengikuti pembelajaran melalui e-learning, sehingga ia sebagai pengajar pun belum yakin untuk menghadapi tantangan di dalam penerapan $e$ learning itu sendiri, sebagai mana yang dikatakan Riska, Paulus dan Ridi (2016), bahwa tantangan yang dihadapi para guru menjadi factor yang menentukan apakah $e$ learning akan terus diterapkan sebagai metode pembelajaran di suatu lembaga pendidikan.

Pada extract 3, persepsi EYB terhadap e-learning yaitu sangat membantu dalam proses pembelajaran meski pengajar tidak berada di dalam kelas, pernyataan ini terlihat dari responnya pada pertanyaan pertama "dengan adanya e-learning kami dapat mengirimkan materi kuliah tanpa harus membiarkan kelas kosong”. Yang artinya, pembelajaran dapat terus dilaksanakan meski pengajar dan pelajar tidak berada pada satu ruangan yang sama. Hal initerkait dengan pendapat Sri Rahayu Candrawati (2010) bahwa proses belajar mengajar menjadi sangat fleksibel karena siswa/mahasiswa bisa belajar sesuai dengan waktu yang mereka miliki. Sebagaimana yang dikatakan juga oleh EYB bahwa Ia memiliki tanggung jawab lain yang bukan hanya mengajar sehingga dengan adanya e-learning Ia dapat menjalankan semua tugasnya secara bersamaan. Secara tidak langsung, hal tersebut merupakan salah satu keunggulan dalam e-learning yang tidak diungkapkan 
EYB dalam pernyataannya saat merespon pertanyaan mngenai keuntungan e-learning.

Sehingga, EYB menyetujui agar $e$ learning diterapkan untuk kedepannya sebagaimana yang Ia katakan "Jika dilihat dari perkembangan dunia Pendidikan saat ini yang lebih banyak berbasis pada teknologi informatika, maka menurut saya sangat baik untuk di terapkan kedepannya dengan tidak lupa menyiapkan sumber daya manusianya (pengajar) serta fasilatas penunjang yang memadai". Pada pernyataan EYB tersebut, Ia tidak mengatakan $e$ learning wajib diterapkan, namun hanya berkata "sangat baik untuk diterapkan". Hal tersebut menandakan bahwa EYB belum terlalu yakin untuk penerepan e-learning sebagai media pembalajaran.

Ketidakyakinan tersebut diperkuat dengan pernyataannya yang dilanjutkan dengan "dengan tidak lupa menyiapkan sumber daya manusianya (pengajar) serta fasilatas penunjang yang memadai”. Dapat diartikan bahwa jika ingin menerapkan mewajibkan e-learning dalam dunia pendidikan, maka suatu instansi pendidikan harus siap memfasilitasi segala hal yang berpengaruh untuk mendukung kesuksesan hasil yang dicapai melalui e-learning tersebut, baik dari segi pengajar yang mumpuni dan segi fasilitas penunjang system e-learning itu sendiri.

EYB berkata demikian karena menyadari minimnya interaksi antara pengajar dan pelajar, serta kurangnya pengetahuan pengajar dalam penggunaan teknologi informatika. Seperti yang Ia $8 \mid J u r n a l$ Patria Bahari katakan mengenai kekurangan dari $e$ learning itu sendiri. Dalam hal ini, Instansi pendidikan harus siap untuk meberi pelatihan khusus kepada pengajar atau pun pelajar mengenai system yang diterapkan dalam pengaplikasian e-learning. Sehingga, pengajar harus siap menjawab tantangan dalam menerapkan e-learning sebagai media pembelajaran. Sebagaimana yang telah diutarakan oleh Riska, Paulus dan Ridi (2016), bahwa Faktor keberhasilan dalam pembelajaran menggunakan media $e$ learning akan menjawab bagaimana cara mengatasi tantangan dari penggunaan $e$ learning, yakni pengajar dan pelajar itu sendiri. Hal tersebut sangat berkaitan dengan respon pelajar dalam mengikuti kegiatan pembelajaran melalui e-learning. Pelajarakan berespon positif apabila memiliki fasilitas teknologi dan intrnet yang memadai seperti yang dikatakan EYB bahwa "siswa memiliki respon yang positif dengan adanya elearning selama tersedianya jaringan internet dan perangkat computer atau HP yang muтpuni".

Selain itu, EYB semakin termotivasi dalam menyediakan konten materi dikarenakan segala aktifitas pembelajaran dapat diakses dengan melalui internet, mulai dari pengumpulan, penyiapan, hingga penyajian materi, serta memiliki referensi yang luas dengan memanfaatkan fasilitas internet. Seperti yang dikatakannya mengenai keuntungan e-learning "Pengumpulan, penyiapan dan penyajian materidapatdilakukandengancepat dan mudah serta memiliki referensi yang 
memadai karena dibantu akses internet yang luas". Sebagaimana yang dikatakanAslan (2017), bahwa pengajar bukan hanya untuk ditiru, tetap mereka harus mampu memotivasi peserta didiknya agar semangat dalam belajar.

EYB juga melakukan inovasi yang nyata dalam pembuatan konten materi dengan menyajikan informasi bahan ajar melalui penggunaan teknologi. Hal ini dapat dilihat dari responnya bahwa "Yang saya lakukan adalah dengan menyajikan materi dalam bentuk Microsoft power point atau Power point slide show serta menampilkan video youtube yang ada hubungannya dengan materi". Pernyataan tersebut memberi pembuktian terhadap yang telah dikatakan Ahmad Cucus dan Yuthsi Aprilinda (2016), bahwa konten harus diperhatikan lebih utama karena dalam e-learning peserta belajar memperoleh materi dengan proporsi lebih besar dari membaca isi materi secara mandiri ketimbang bertatap muka langsung dengan pengajar. Dapat disimpulkan bahwa penyajian materi dalam bentuk video dapat meningkatkan motivasi pelajar untuk mengikuti pembelajaran melalui e-learning.

Pada Extract 4, AR berpendapat bahwa penerapan e-learning kurang efektif jika dilakukan pada institusi yang mengacu pada pendidikan vokasi karena proses pembelajaran lebih mengutamakan kegiatan praktek dibandingkan eori. Sehingga, pengajar butuh lebih banyak waktu unntuk berinteraksi dengan pelajar secara langsung atau tatap muka secara langsung. Maka dari itu AR mengungkapkan bahwa e-learning tidak wajib diterapkan pada insititusi yang berlandaskan pendidikan vokasi, meski beberapa pembelajaran mungkin layak untuk melakukan pembelajaran melalui e-learning. Pernyataan tersebut dapat dilihat pada respon AR terhadap persepsinya mengenai $e$ learning "Untuk pendidikan yang mengacu pada aturan Vokasi, proses transfer knowledge saya anggap kurang efektif. Berhubung perbandingannya praktek butuh tatap muka yg lebih banyak ketimbang belajar dlm kelas", serta dapat dilihat pada responnya mengenai apakah e-learning wajib diterapkan kedepannya "untuk sebagian pembelajaran mungkin butuh, namun sebagian proses pembelajaran sepertinya kurang efektif, apalagi jika pendidikan vokasi". Sangat terlihat jelas bahwa AR tidak setuju jika e-learning wajib diterapkan kedepannya, terutama pada lembaga pendidikan yang mengacu pada system vokasi.

Jika diselaraskan dengan pernyataan Rahayu Candrawati (2010) bahwa proses belajar mengajar menjadi sangat fleksibel karena siswa/mahasiswa bisa belajar sesuai dengan waktu yang mereka miliki, maka pendapat AR ini bertolak belakang dengan pernyataan tersebut. Di mana, sebagai pengajar yang mengampuh mata kuliah jurusan khusus pada lembaga pendidikan yang berlatarkan vokasi, seperti yang diungkapkan sebelumnya, maka peserta didik tidak memiliki waktu yang fleksibel untuk menerapkan pembelajaran secara praktek, namun harus menyesuaikan waktu pembelajaran mereka dengan jadwal yang 
telah diatur oleh instansi, serta pembelajaran praktek memerlukan pertemuan tatap muka langsung dalam penerapannya.

AR mengutarakan bahwa dengan adanya e-learning, Ia semakin termaotivasi untuk membuat bahan ajar atau konten materi melalui video lalu diupload ke youtube. Seperti yang ia utarakan mengenai inovasi pengajar dalam membuat konten mater "Saya membuat video pembelajaran dan menguploadnya dalam youtube", serta dapat pula dilihat pada responnya mengenai keuntungan pengajar terhadap e-learning "bagi saya memotivasi membuat bahan ajar berupa video tutorial, semakin tertantang". Motivasi yang di dapatkannya dapat menjadi contoh kepada pelajar untuk tetap semangat mengikuti pembelajaran melalui e-learning sekalipun pembalajaran praktek harus dilakukan dengan jarak jauh sebagai mana yang dikatakan Aslan (2017), bahwa pengajar bukan hanya untuk ditiru, tetap mereka harus mampu memotivasi peserta didiknya agar semangat dalam belajar. Hal tersebut harus dicontohi oleh pengajar sendiri dengan menunjukkan semangat dalam mengajar.

Selain itu, melalui inovasi yang Ialakukan dengan cara membuat konten materi, lalu menguploadnya ke youtube denga nmaksud dapat diakses kapan pun oleh peserta didik, membuktikan bahwa pengajar harus memiliki banyak ide dan kreatifitas dalam menyusun konten materi melalui $e$ learning. Sebagaimana yang dinyatakan oleh Ahmad Cucus dan Yuthsi Aprilinda (2016), bahwa dalam proses belajar mengajar, konten pembelajaran adalah hal yang paling penting dalam pembelajaran jarak jauh (e-learning). Sehigga, pengajar dapat menjawab tantangan sebagai faktor penentu kesuksesan ketika harus menerapkan pembelajaran melalui $e$ learning (Riska, Paulus, dan Ridi, 2016).

Pada extract 5, mengenai persepsi pengajar terhadap e-learning, RWR menyatakan "Maka saya sangat setuju dengan program pengajaran e-learning, tentu saja harus didukung dengan prosedur dan dasar yang relevan sesuai STCW 2010 sehingga mutu pendidikan dapat terjamin". Dari pernyataan tersebut, RWR sebagai pengajar pada bidang pendidikan maritime mendukung proses pembelajaran melalui $e$ learning yang direlevansikan dengan aturan STCW 2010 pada dunia maritim.

Pandangan tersebut berdasarkan perkembangan zaman yang terjadi dimana teknologi sangat mempengaruhi dunia pendidikan. Persepsinya selaras dengan melihat respon pelajar yang antusias untuk selalu hadir di dalam pembelajaran melalui $e$ learning yang dapat dilihat dari respon RWR"Para pelajar sangat antusias dalam pelaksanaan pembelajaran jarak jauh (elearning), hal ini dapat dibuktikan dengan respon para peserta yang selalu aktif untuk hadir dan mengikuti proses pembelajaran secara jarak jauh”. Di samping itu, RWR melihat beberapa keuntungan yang diperoleh dalam proses pembelajaran melalui $e$ learning, yakni "fleksibiltas waktu dan tempat" yang telah diterangkan oleh RWR sendiri. Di mana pendapat itu sangat relevan dengan pernyataan Sri Rahayu Candrawati 
(2010) bahwa proses belajar mengajar menjadi sangat fleksibel karena siswa/mahasiswa bisa belajar sesuai dengan waktu yang mereka miliki.

RWR juga melakukan inovasi di dalam e-learning dengan membekali keterampilan diri dalam penguasaan teknologi. Di mana dapat dilihat pada pendapatnya "Cara pengajar dalam berinovasi adalah dengan membekali diri dalam keterampilan mengoperasikan Komputer dan juga menggunakan aplikasi-aplikasi yang sangat membantu dalam proses pembelajaran seperti Kahoot, Sevina, Moodle, Youtube dan lain-lain". Yang mengartikan bahwa dia mengkombinasikan aplikasi sosial media yang ada dengan pembuatan konten materi yang akan disampaikan kepada pelajar. Hal tersebut menandakan bahwa sebagai pengajar, RWR sangat memperhatikan konten materi yang dibuat begitu penting di dalam pembelajaran melalui e-learning (Ahmad Cucus dan Yuthsi Aprilinda, 2016).

Namun, RWR juga menyadari beberapa kendala yang dihadapainya ketika melakukan proses pembelajaran melalui e-learning, yakni"Interaksi secara langsung antara pengajar dan siswa akan berkurang, cenderung mengabaikan aspek sosial, tidak semua tempat tersedia fasilitas internet, pelajar tidak menguasai computer, pelajar yang tidak memiliki motivasi belajar yang tinggi akan mengalami kegagalan". Kendalakendala tersebut adalah tantangan bagi pengajar itu sendiri di dalam e-learning. RWR sebagai pengajar harus memiliki motivasi yang tinggi untuk tetap semangat di dalam proses $e$-learning guna mempengaruhi energi positif terhadap para pelajar. Di mana pengajar bukan hanya untuk ditiru, tetapi juga bisa memotivasi pelajar untuk mengikuti proses pembelajaran hingga selesai (Aslan, 2017).

Sehingga, untuk mewajibkan penerapan e-learning pada institusi belatarkan pendidikan vokasi, RWR harus bisa menjawab tantangan-tantangan yang di dalamnya termasuk pada kendala yang diungkapkannya serta inovasi yang dilakukannya. Sebagaimana yang telah dikatakan oleh Riska, Paulus dan Ridi (2016), bahwa dengan perkembangan pendidikan saat ini, di mana situs atau media pembelajarantelahdigunakan oleh para pengajar dalam melakukan proses belajar mengajar (PBM) dalam menggunakan media pembelajaran e-learning, tantangan yang dihadapi para guru menjadi factor yang menentukan apakah e-learning akan terus diterapkan sebagai metode pembelajaran di suatu lembaga pendidikan. Faktor keberhasilan dalam pembelajaran menggunakan media e-learning akan menjawab bagaimana cara mengatasi tantangan dari penggunaan e-learning.

Dapat disimpulkan bahwa meski program pembelajaran melalui e-learning pada pendidikan vokasi diterapkan dengan merelevansikan STCW 2010 seperti yang dikatakan RWR "Saya lebih setuju kegiatan e-learning yang dilakukan harus mempunyai pedoman, dasar dan prosedur yang baku mengacu pada STCW 2010 agar mutu Pendidikan dan pelatihan kita terjaga yang 
dipadukan dengan tatap muka (blended learning) karena kita adalah pelaku sekolah Vokasi (boarding school) yang lebih mengedepankan praktek.", tetapi pengajar tidak memiliki motivasi dan inovasi yang tinggi sebagai pelaku pendidik, maka tujuan dari proses pembelajaran itu sendiri akan sulit dicapai.

Selainitu, pada pernyataan RWR di atas mengartikan bahwa selain melakukan $e$ learning, institusi perlu melakukan proses pembalajaran melalui tatap muka dikarenakan pada pendidikan vokasi pembelajaran praktek lebih membutuhkan banyak waktu dibandingkan teori. Oleh karena itu, peneliti menyimpulkan bahwa RWR belum sepenuh yakin untuk menerapkan e-learning di dalam pendidikan vokasi, tetapi dia juga mengharapkan diberlakukannya blended learning sebagaimana yang telah dikatakannya. Sehingga, dapat dilihat bahwa pengajar belum yakin sepenuhnya untuk melakukan proses pembalajaran melalui e-learning.

\section{KESIMPULAN}

Berdasarkan hasil dari penelitian ini, peneliti menyimpulkan bahwa tantangantantangan yang dihadapi pengajar di dalam elearning membuat mereka untuk lebih berinovasi dalam membuat konten sebagai bahan ajar pada pembelajaran jarak jauh ini (Ahmad Cucus \& Yuthsi Aprilinda, 2016). Tiap-tiap pengajar mengalami kesulitan tersendiri dalam menerapkan e-learning kepada para pelajar mengikuti mata kuliah yang diampuh. Sebagian besar pengajar merasa kesulitan ketika harus memberikan materi praktek kepada pelajar, karena dibutuhkan tatap muka secara langsung untuk dapat melakukan praktek tersebut, serta dapat menilai secara langsung hasil praktek yang dilakukan peserta didik.

Misalnya,dalam penerapan praktek English speaking pada mata kuliah bahasa atau pun praktek yang berhubungan terhadap mata kuliah pada jurusan yang diampuh pelajar. Di mana, instansi ini adalah pendidikan yang berlatarkan vokasi pada bidang maritim sehingga mengacu pada aturan IMO (International Maritime Organization) STCW 2010. Oleh karena itu, pengajar harus mengembangkan potensi diri mengikuti perkembangan zaman di era 4.0 ini. Di mana, teknologi sangat berperan penting dalam dunia pendidikan. Sehingga dalam menggunakan media pembelajaran elearning, tantangan yang dihadapi para pengajar menjadi factor yang menentukan apakah e-learning akan terus diterapkan sebagai metode pembelajaran di suatu lembaga pendidikan. Faktor keberhasilan dalam pembelajaran menggunakan media $e$ learning akan menjawab bagaimana cara mengatasi tantangan dari penggunaan $e$ learning (Riska, Paulus \& Ridi, 2016). 


\section{DAFTAR PUSTAKA}

Ahmad C, Yuthsi A. 2016. Pengembangan E-Learning Berbasis Multimedia Untuk Efektifitas Pembelajaran Jarak Jauh. Jurnal Sistem Informasi dan Telematika, ISSN: 2087-2062

Aslan. 2017. Pumping Teacher dalamTantangan Pendidikan Abad 21. Jurnal Madrasah Ibtidaiyah, Volume 2, Nomor 2, April 2017, ISSN: 2476-9703

Crotty, Michael. (1998). The Foundations of Social Research. Meaning and Perspectives in the Research Process. St. Leonards: Allen \& Unwinn.

Miles, M. B., \& Huberman, A. M. 1984. Qualitative data analysis: A sourcebook of new methods. In Qualitative data analysis: a sourcebook of new methods. Sage publications.

Riska A, Paulus IF, Ridi F. 2016. Sejarah, Tantangan, dan Faktor Keberhasilan dalam Pembelajaran E-Learning. Seminar Nasional Sistem Informasi Indonesia, Volume 2016.

Sri Rahayu Candrawati. 2012. Pemafaatan E-Learning dalam Pembelajaran. Jurnal Cakrawala Kependidikan Volume. 8. No. 2. September 2010:101-203

Sugiyono. 2010. Metode Penelitian Pendidikan Pendekatan Kuantitatif, Kualitatif dan R\&D. Bandung: Alfabet 